\title{
Compounds detection and inhibition activity of chloroform and ethyl acetate extracts of Schizophyllum commune on some cancer cell types
}

\author{
NURAENI EKOWATI", ARIS MUMPUNI, NUNIEK INA RATNANINGTYAS, ARDHINI RIN MAHARNING \\ Faculty of Biology, Universitas Jenderal Soedirman. Jl. Dr. Soeparno 63, Purwokerto Utara, Banyumas 53122, Central Java, Indonesia. \\ Tel. +62-281-638794,Fax: +62-281-631700, `email: nuraeniekowati29@gmail.com
}

Manuscript received: 22 October 2020. Revision accepted: 28 November 2020.

\begin{abstract}
Ekowati N, Mumpuni A, Ratnaningtyas NI, Maharning A. 2020. Compounds detection and inhibition activity of chloroform and ethyl acetate extracts of Schizophyllum commune on some cancer cell types. Biodiversitas 21: 5865-5871. Schizophyllum commune Fr.is a potential fungus utilized as a drug, including a cancer drug expectant. In Indonesia, the fungus' capability to suppress the growth of certain types of cancer cells has not been widely reported. The purposes of this study were (i) to determine the bioactive compound group from $S$. commune using organic solvents chloroform and ethyl acetate, (ii) to determine the $\mathrm{IC}_{50}$ values of $S$. commune bioactive compounds using cancer cell lines HeLa, MCF7, T47D and WiDr, (iii) to find out the mechanism of apoptosis. The research was carried out experimentally using a pure culture of four types of cancer cell lines. Anticancer activity test was conducted by a cytotoxic test using MTT [3- (4,5- dimethylthiazol -2-yl) -2.5-diphenyl tetrazolium bromide], and apoptosis test. Data analysis was performed with linear regression analysis, and the apoptosis test was analyzed descriptively. The results showed that the bioactive compounds produced by $S$. commune are alkaloids, terpenoids, and flavonoids. S. commune bioactive compounds potentially inhibit the four cancer cell lines used with $\mathrm{IC}_{50}$ values ranging from 5.44 to $420.48 \mathrm{ug} / \mathrm{mL}$. Best result was obtained from $S$. commune extract of chloroform in T47D cells with $\mathrm{IC}_{50}=5.44 \mathrm{ug} / \mathrm{mL}$ and are able to induce apoptosis.
\end{abstract}

Keywords: Bioactive compounds, cancer cell lines, cytotoxic test, Schizophyllum commune

\section{INTRODUCTION}

The global awareness of cancer as the second-largest causal agent of death in people of various ages and backgrounds has led to many research efforts and clinical studies in the fight against the disease. According to Cancer Research UK, 17 million new cases have been reported, and among them, 9.6 million patients ended up to death in 2018. If it continues at such a rate, by 2040, there will be 27.5 million new cancer patients each year. Unprecedented advances in synthetic chemistry, omics studies to pinpoint target genes/proteins, and efficient drug delivery systems have made it easier for researchers to develop phytochemicals as efficient anticancer drugs (Ashraf 2020). Torre et al. (2015) state that the continuing magnitude of the cancer problem and the failure of conventional chemotherapy of the advanced invasive disease to affect the significant reduction in the mortality rates for the common forms of epithelial malignancies such as carcinoma of lung, colon, breast, prostate, etc., indicate that new approaches to the control of cancer are critically needed.

Cervical cancer, breast cancer, and colon cancer are malignant types of cancer with a high mortality rate. Chemotherapy treatment is a method often used but have not provided satisfactory results. Compounds from plants and fungi can be used to inhibit the growth of cancer cell lines. Recently, much attention has been focused on polysaccharides and secondary metabolites from natural sources such as bacteria, fungi, algae, and plants (Moharib et al. 2014). Khatun et al. (2012) stated that Basidiomycete fungi (mushrooms) are a gift that has excellent prospects as food and medicinal purpose. Some researchers had shown that mushrooms can produce new secondary metabolites and have a broad spectrum of biological activities because they have diverse chemical structures.

Schizophyllum commune Fr. is one type of macroscopic fungi that could potentially produce bioactive compounds. $S$. commune has long been known as a fungus that can be used as a medicine, although its properties are not certainly known. This fungus is a Phylum Basidiomycota member, living wildly in nature. Determining its potential as an anticancer can be done by an in-vitro test using cancer cells, including the cancer cell lines HeLa, MCF7, T47D, and WiDr. Assay on $S$. commune mushroom bioactive compounds on cancer cell lines until now has never been done.

The potential of macroscopic fungi as a medicinal ingredient has been reported by Ekowati et al. (2017), namely Pleurotus ostreatus, which is a member of the Basidiomycota capable of producing secondary metabolites anticancer activity. It was also reported that in the species, there are 23 types of secondary metabolites have been identified. Ethyl acetate extract of $P$. ostreatus isolated from Madiun Indonesia showed the best results with $\mathrm{IC}_{50}=$ $107.59 \mu \mathrm{g} / \mathrm{mL}$. HeLa cell lines proliferation kinetics analysis showed that the application of bioactive compounds $100 \mu \mathrm{g} / \mathrm{mL}$ increased the death of HeLa cell lines and incubation time length. Hikam et al. (2019) reported that the Auricularia auricula mycelium's chloroform extract showed the best results with $\mathrm{IC}_{50}=$ $264.87 \mu \mathrm{g} / \mathrm{mL}$. An important finding obtained after the 
double staining process was that chloroform extract of $A$. auricula could induce HeLa cell lines death by apoptosis. The search for new anticancer drugs and other medicinal substances from higher Basidiomycetes and the study of these edible mushrooms' medicinal values have been of great interest. Thus, several authors have combined the use of mushrooms for both nutritional and medicinal purposes.

The purposes of this study were (i) to determine the bioactive compound group from $S$. commune using organic solvents chloroform and ethyl acetate, (ii) to determine the $\mathrm{IC}_{50}$ values of $S$. commune bioactive compounds using cancer cell lines HeLa, MCF7, T47D, and WiDr, (iii) to find out the mechanism of apoptosis

\section{MATERIALS AND METHODS}

The research was conducted in Mycology Laboratory, Faculty of Biology, University of General Soedirman, Purwokerto, Indonesia and Parasitology Laboratory, Faculty of Medicine, Universitas Gadjah Mada, Yogyakarta, Indonesia.

\section{Materials}

Materials used were: Schizophyllum commune, pure culture of cancer cell lines (HeLa, MCF7, T47D and WiDr cells), Potato Dextrose Agar, dimethylsulfoxide (DMSO), chloroform, sodium dodecyl sulfate, medium Rosewell Park Memorial Institute (RPMI ) 1640 (Sigma), Dulbecco's Modified Eagle Medium (DMEM), fetal bovine serum (FBS) $10 \%$ (v / v) (Gibco), reagent stopper AcidIsopropanol, penicillin-streptomycin 1\% (v / v) (Gibco), hepes (Sigma), fungison $0.5 \%$ (v / v (Gibco)), $70 \%$ ethanol, [3- (4,5-dimetiltiazol-2-yl) -2.5-diphenyl tetrazolium bromide] (MTT kit, Sigma), object glass, acridine orangeethidium bromide.

The tools used were glassware, Bunsen burner, inoculation tools, laminar airflow, incubator cabinet, oven, freeze dryer, vacuum pump, orbital shaker, analytical balance, refrigerator, incubators $\mathrm{CO}_{2} 5 \%$, Inverted Microscope, Fluorescent Microscope, hemocytometer, Pasteur pipette, 96-well plate (Nunc) 24-well plate (Iwaki), coverslip of $13 \mathrm{~mm}$ diameter (Thermanox), ELISA Reader, micropipette, cell counter, centrifuge Sorvall MC $12 \mathrm{~V}$ (Dupont), $15 \mathrm{~mL}$ centrifuge tube, and autoclave.

\section{Methods}

\section{Preparation of $\mathrm{S}$. commune extract}

The dry mycelium was extracted by maceration method. The dry mycelium was mashed, then added with $25 \mathrm{~mL}$ of chloroform solvent and macerated for $1 \times 24$ hours, after 24 hours the mycelium was separated from the solvent. The separated mycelium was extracted again with chloroform solvent for a second time and remacerated for $1 \times 24$ hours then the mycelium was separated again from the solvent. The mycelium that was separated from the chloroform solvent was extracted again using ethyl acetate solvent in the same way. The separation process is done by filtering using filter paper. The results of the first and second extraction are mixed, then evaporated until a thick extract is obtained.

\section{Identification of secondary metabolite compound group} (Cai 2014; Kumar et al. 2013)

The detection of bioactive compounds of mycelium extract $S$. commune was carried out by Thin Layer Chromatography (TLC) to determine the presence or absence of alkaloid, terpenoid, and flavonoid compounds. Silica gel F254 thin layer chromatography plates were cut to size $10 \times 10 \mathrm{~cm}$, then outlined the upper and lower borders. The $S$. commune extract was dotted at the center of the lower boundary as much as $8 \mu \mathrm{l}$, then allowed to dry and put into a saturated chamber with the mobile phase.

In alkaloid identification, the stationary phase used was silica gel $\mathrm{F}_{254}$ and the mobile phase used for chloroform extract was methanol: hexane: glacial acetic acid (8: 2: $0.5)$, and for ethyl acetate extract was methanol: hexane: glacial acetic acid (8: 1: 0.5). The eluted spots were detected by spraying Dragendroff reagent and then heated at $100^{\circ} \mathrm{C}$ for 5 minutes. The presence of alkaloids is indicated by the formation of yellow or orange patches.

In terpenoid identification, the stationary phase used was silica gel $\mathrm{F}_{254}$, and the mobile phase for chloroform and ethyl acetate extracts was: n-hexane: ethyl acetate: glacial acetic acid (8: 2: 0.5 ). The eluted spots were detected by spraying vanillin-sulfuric acid and then heated at $100^{\circ} \mathrm{C}$ for 5 minutes. The formation of blackish-purple spots indicates the presence of terpenoids.

In identifying flavonoids, the stationary phase used was silica gel F254, and the mobile phase for chloroform and ethyl acetate extracts was n-hexane: ethyl acetate: glacial acetic acid (8: 2: 0.5$)$. The eluted spots were detected by spraying $\mathrm{AlCl} 3$ reagent and then seen on $366 \mathrm{~nm}$ UV light. The formation of blue-green spots indicates the presence of flavonoids. For each eluted spot, the Retardation Factor (Rf) value is calculated with the following formula:

$$
\text { Retardation Factor }(\mathrm{Rf})=\frac{\text { The distance travelled by the compound }}{\text { The distance moved by the solvent surface }}
$$

Anticancer activity assay was done by using four types of cancer cells, i.e., cervical cancer cells (HeLa), breast cancer cells (MCF7 and T47D), and colon cancer cells (WiDr). The method used was experimental by examining multiple concentrations of the extract in cell culture, cytotoxic examination elaborated secondary metabolites extract treatment with concentration (in $\mu \mathrm{g} / \mathrm{mL}$ ) $0 ; 31.25$; $62.50 ; 125 ; 250 ; 500$ and 1,000 , respectively. The variables measured were the living cells and the $\mathrm{IC}_{50}$ (Inhibition Concentration 50), cancer cell lines (HeLa, MCF7, T47D, and WiDr), and the mechanism of cell death through apoptosis test.

\section{Anticancer test procedures for several types of cancer cell lines (Meerloo 2011; Ackermann and Tardito 2019)}

Preparation of culture media for cancer cell lines (RPMI and DMEM). Preparation and multiplication of HeLa, MCF7, T47D, and WiDr cell lines. HeLa, MCF7, and T47D cell lines were cultured using RPMI media and WiDr cell lines were cultured using DMEM media. Dilution of secondary metabolites extract of $S$. commune each treatment with concentration (in $\mu \mathrm{g} / \mathrm{mL}$ ) $0 ; 31.25$; $62.50 ; 125 ; 250 ; 500$ and 1,000 . Cytotoxic activity assay of 
each cancer cell line.

Cytotoxicity assay with MTT method [3- (4,5dimethylthiazol -2-yl) -2.5-diphenyl tetrazolium bromide]. The number of cells of each of these cancer cell lines multiplied and counted as much as $10^{4}$ per mL. Cancer cell lines in the medium RPMI or DMEM that has been calculated are cultured in 96 wells plate, incubated in an incubator cabinet with a stream of $5 \%$ carbon dioxide at $37^{\circ} \mathrm{C}$ for 24 hours. After incubation for 24 hours, the cells' growth was observed; if the cells normally live (healthy), the assay was conducted using extracts of bioactive compounds (chloroform and ethyl acetate extracts) from $S$. commune. The chloroform and ethyl acetate extracts were prepared and dissolved in the medium to be used at concentrations (in $\mu \mathrm{g} / \mathrm{mL}$ ) $0 ; 31.25 ; 62.50 ; 125 ; 250 ; 500$ and 1,000. Each of the $100 \mathrm{~mL}$ concentrations is taken and put in the plate, which already contains cells, each with three replicates, plus control cells without extracting and extracting media without cells.

Furthermore, the cells were incubated in an incubator with a $5 \%$ carbon dioxide stream at $37^{\circ} \mathrm{C}$ for 24 hours. At the end of incubation, cell morphology was observed using an inverted microscope and photographed for each treatment. In each of the wells was added $10 \mathrm{~mL}$ of MTT $2.5 \mu \mathrm{g} / \mathrm{mL}$ in PBS. The 96 well plates were incubated in an incubator with a stream of $5 \%$ carbon dioxide at $37^{\circ} \mathrm{C}$ for 4 hours. After 4 hours, the MTT reaction was stopped by adding $100 \mathrm{~mL}$ reagent-stopper Acid Isopropanol, then incubated 12 hours at room temperature. Absorption of color was read by ELISA reader at a wavelength of 550 $\mathrm{nm}$. Results of absorbance are converted in life percentages of HeLa cells; thus, the examined compounds' $\mathrm{IC}_{50}$ values would be obtained.

DNA staining proceeded with acridine orange/ethidium bromide. Coverslip was grown into a 24-well plate, and the cells are distributed on it, incubated in an incubator with a stream of $5 \%$ carbon dioxide at $37^{\circ} \mathrm{C}$ for 24 hours. The number of cells required for the apoptosis test was $5 \times 10^{4}$ cells / well $\left(5 \times 10^{4}\right.$ cells / $1000 \mu$ l media). Observations mechanisms of cell lines death (by apoptosis and necrosis) are done with Fluorescent Microscope.

\section{Data analysis}

Cytotoxicity test data in the form of absorption responses (absorbance) is converted into a percent of the life of cancer cells by the following formula:

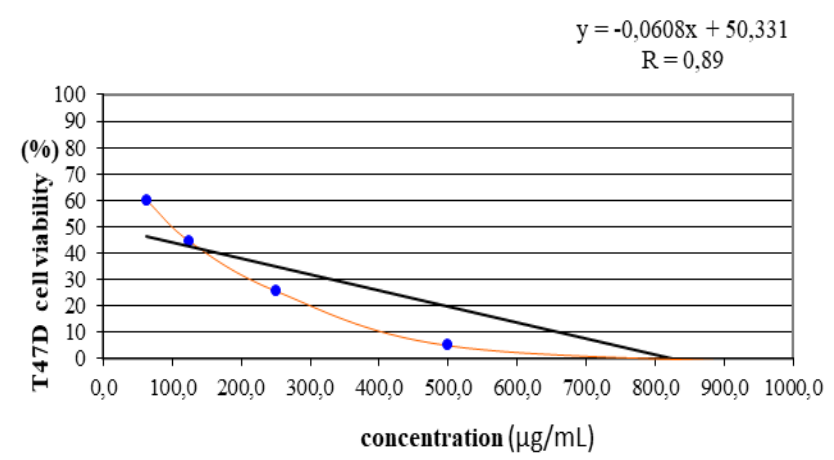

Figure 1. T47D cell viability by chloroform extract of Schizophyllum commune for 24 hours, with the value $\mathrm{IC}_{50}=5,44$ $\mu \mathrm{g} / \mathrm{mL}$
$\%$ of living cell $=\frac{\text { absorbance of treatment }- \text { absorbance of media control } x 100 \%}{\text { absorbance of control cells }- \text { absorbance of media control }}$

From these results the $\mathrm{IC}_{50}$ (Inhibition Concentration 50) was calculated using linear regression analysis

\section{RESULTS AND DISCUSSIONS}

The results showed that $S$. commune could produce bioactive compounds that could inhibit the growth of HeLa, MCF7, T47D, and WiDr cells line, with the percentage of inhibition varied. Cytotoxic test results are presented in Table 1.

The results of $\mathrm{IC}_{50}$ values for some cancer cell lines ranged from 5.44 to $420.48 \mathrm{ug} / \mathrm{mL}$. Chloroform extract showed the smallest $\mathrm{IC}_{50}$ values for all four types of cancer cells line. This indicates that bioactive compounds in chloroform extract are more potent in inhibiting the growth of cancer cells. Types of cell lines that most sensitive to bioactive compounds from $S$. commune is T47D cell line with $\mathrm{IC}_{50}=5.44 \mathrm{ug} / \mathrm{mL}$. T47D cell lines, which are breast cancer cells, are often used to test cytotoxic in vitro. $\mathrm{IC}_{50}$ value obtained is relatively low and has the potential to be developed. The smaller the $\mathrm{IC}_{50}$ value indicates the more active extracts that are used to kill cancer cell lines. Morris et al. (2017) stated that Pleurotus has the potential to inhibit NB4 human leukemia cells, at a concentration of $200 \mu \mathrm{g} / \mathrm{mL}$, by $82 \%$ and also stimulate NB4 cell apoptosis.

Viability chart/graph of T47D cancer cell lines treated with extracts of chloroform, and ethyl acetate $S$. commune is presented in Figures 1 and 2.

Table 1. IC 50 values in the bioactive compound of Schizophyllum commune cytotoxic test using HeLa, MCF7, T47D, and WiDr cells line

\begin{tabular}{lcccc}
\hline \multirow{2}{*}{ Kind of extract } & \multicolumn{4}{c}{ IC $_{\mathbf{5 0} \text { value of cancer cell line types }(\boldsymbol{\mu g} / \mathbf{m L})}$} \\
\cline { 2 - 5 } & HeLa cell & T47D cell & MCF7 cell & WiDr cell \\
\hline Chloroform & 34.48 & 5.44 & 340.41 & 19.44 \\
Ethyl acetate & 57.66 & 15.26 & 420.48 & 252.48 \\
\hline
\end{tabular}

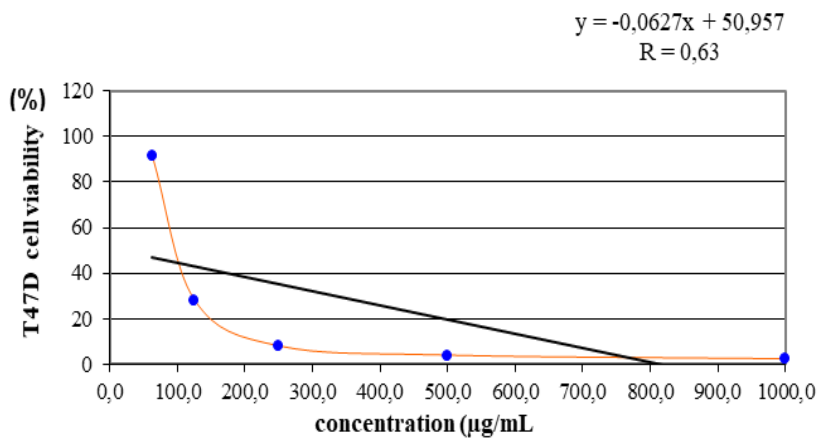

Figure 2. T47D cell viability by ethyl acetate extract of Schizophyllum commune for 24 hours, with the value $\mathrm{IC}_{50}=15,26$ $\mu \mathrm{g} / \mathrm{mL}$ 
The regression analysis (Figures 1 and 2) showed that the $\mathrm{IC}_{50}$ value of chloroform and ethyl acetate extract is relatively low, i.e., below $100 \mu \mathrm{g} / \mathrm{mL}$. Cytotoxic assay results showed that the increasing levels of bioactive compounds of $S$. commune extract led to a decrease in the percentage of living T47D cell lines. This suggests that the bioactive compounds of $S$. commune are able to kill T47D cell lines due to higher levels of extract (dose-dependent). Liu et al. (2014) reported that the $\mathrm{IC}_{50}$ for GNM oral cancer cell lines (squamous cell carcinoma cell lines) is 281.9 $(\mu \mathrm{g} / \mathrm{mL})$. Cancer cell lines died by apoptosis mechanism, and the apoptosis percentage increased with the increasing concentrations of the extract. The apoptosis mechanism is proceeded by the inhibition of mitochondrial membrane permeability through the Bax protein's action.

Anticancer experiments with bioactive compound of Inonotus obliquus have been conducted; triterpenoids from the extract of I. obliquus, especially Inotodiol, can dramatically inhibit the walker 256 carcinosarcomas, MCF7 human mammary adenocarcinoma, and leukemia cells P388. Thus, most bioactive substances from mushrooms have been reported to exert their anticancer activity by blocking cell cycle progression and triggering tumor cell apoptosis (Song et al. 2013). The MTT test results showed that $200 \mu \mathrm{g} / \mathrm{mL}$ of crude ethanol extract significantly inhibited the proliferation of KKU-M213 by $50 \%$ compared to the effect on the proliferation of KKU-M213 cells (Menakongka et al. 2019). The ethyl acetate extract of endophytic fungi inhibited colon cancer cells with $\mathrm{IC}_{50}=$ $20.80 \mu \mathrm{g} / \mathrm{mL}$ (Arifni et al. (2017). Hikam et al. (2019) reported that chloroform extract of Auricularia auricula mycelium showed the best results with $\mathrm{IC}_{50}=264.87 \mu \mathrm{g} / \mathrm{mL}$

According to Meiyanto et al. (2008), IC $\mathrm{I}_{50}$ values below $100 \mu \mathrm{g} / \mathrm{mL}$ test showed that the extract has potential as bioactive metabolites that can be used as an agent for cancer chemoprevention. Research has been done by Meiyanto et al. (2008) showed that the ethanol extract of betel nut (Areca catechu) inhibits breast cancer cells (MCF-7) with $\mathrm{IC}_{50}$ of $77 \mu \mathrm{g} / \mathrm{mL}$, and the comparison compound arecoline is $180 \mu \mathrm{g} / \mathrm{mL}$. Faridur et al. (2010)

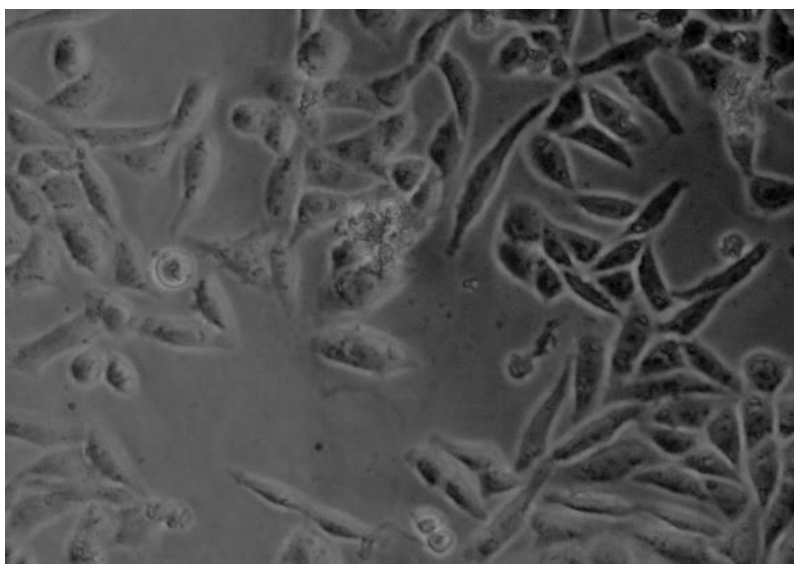

A found out the effect of the extract of $S$. commune on the viability of cancer cells; besides observed using the ELISA Reader to count the number of living cells, cell morphology was also observed using an inverted microscope. Cell morphology is presented in Figure 3.

Figure 3.A shows the T47D healthy cells; the cells appear normal and attached to the base medium. Figure 3B shows the morphology of T47D cell lines that are not normal, showed damage T47D cell lines, the cell has changed shape and seemed intact, into a round shape, and cell shrinkage occurs. Cell lines appear abnormal and split into small dots. According to Ekowati et al. (2017), as a result of the extract of Pleurotus ostreatus, cancer cells die through apoptosis and necrosis mechanisms; however, the mechanism of apoptosis is more dominant.

The results of the next study were to observe the mechanism of cell death by apoptosis. Observation of the apoptotic mechanism was carried out by staining acridine orange-ethidium bromide (double staining). The dead cell lines will turn orange because the ethidium bromide dye enters the dead cells and spreads throughout the cells so that they are orange. In contrast, the living cells are green because the ethidium bromide dye cannot penetrate healthy cells. The image of cell staining can be seen in Figure 4.

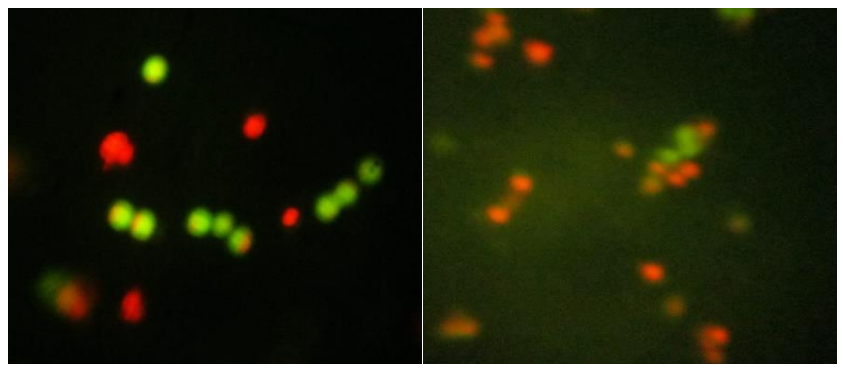

Figure 4. T47D cell lines morphology with acridine orangeethidium bromide staining to show apoptotic cell lines death. Living cells (green), dead cells/apoptosis (orange)

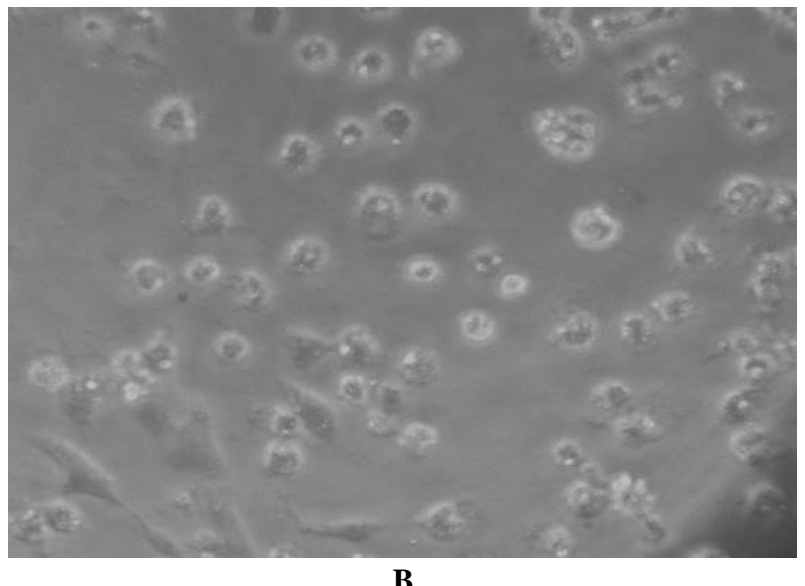

Figure 3. Morphology of T47D cell of cytotoxic test results. A. T47D healthy cells (normal), B. T47D abnormal cells as the effect of the Schizophyllum commune chloroform extract with a concentration of $31.25 \mu \mathrm{g} / \mathrm{mL}$ 
The dead cells fluoresce orange; this indicates a loss of membrane permeability in some cells due to exposure to the extract. As a result, ethidium bromide can enter cells and cause orange fluorescence to indicate cell line death. According to Brady (2007), apoptosis is a programmed cell death that causes an inflammatory reaction, whereas necrotic cell death can cause inflammatory responses in the body. Lee et al. (2015) stated that the ethanol extract of the fungus Cordyceps militaris could inhibit colon cancer cells' growth through a mechanism of inhibition of cell cycle at the $\mathrm{G} 2 / \mathrm{M}$ phase increases apoptosis and expression of $\mathrm{p} 53$ gene. Ethanol extract of $C$. militaris $300 \mu \mathrm{g} / \mathrm{mL}$ can increase apoptosis by $22.5 \%$.

HeLa cell lines treated with $150 \mu \mathrm{g} / \mathrm{mL}$ of the ethanolic extract resulted in more round, skinny, and membrane blabbing. The dead cells and cell debris were also observed. The cells treated with $150 \mu \mathrm{g} / \mathrm{mL}$ of ethyl acetate extract and water extract, separately, were similar to the fate of HeLa cells. The other two cell lines (SiHa and CaSki), when exposed to an earlier concentration of these extracts at $24 \mathrm{~h}$, showed the same trends. All three types of cancer cells treated with Adriamycin (positive control) became round-shaped, while many cells were dead (Ghosh 2020).

\section{Detection of secondary metabolites produced by Schizophyllum commune mycelium}

Mycelia of $S$. commune was extracted using chloroform and ethyl acetate as solvents. The compounds in the extract compounds were analyzed by thin-layer chromatography (TLC) using several reagents for alkaloids, terpenoids, and flavonoids. Thin-layer chromatography is performed several times using various mobile phases with different polarity levels to obtain a solvent that can provide adequate separation and spotting. The TLC results are presented in Table 2.

Based on Table 2, the results of the detection of bioactive compounds by TLC on chloroform and ethyl acetate extracts of $S$. commune for all treatments showed positive results for the presence of alkaloids, terpenoids, and flavonoids. Based on these research results, $S$. commune mushrooms cultured at $\mathrm{pH} 4, \mathrm{pH} 5, \mathrm{pH} 6$, and $\mathrm{pH}$ 7 were able to produce alkaloids, terpenoids, and flavonoids. The growth of $S$. commune at $\mathrm{pH} 4, \mathrm{pH} 5, \mathrm{pH} 6$, and $\mathrm{pH} 7$ did not show any difference in the types of secondary metabolites produced. The results of this study showed the best growth of $S$. commune mycelium was at $\mathrm{pH} 6$ with an incubation time of 25 days, which resulted in a dry mycelium weight of $0.61 \mathrm{~g} / 100 \mathrm{~mL}$ and the presence of secondary metabolites of the alkaloid, terpenoid, and flavonoid groups. According to Abo-Elmag (2014), bioactive compounds that are not found at too extreme $\mathrm{pH}$ can occur due to delayed metabolite production due to inhibition of mycelium growth.

The production of secondary metabolites in fungi is also influenced by the growth medium used. The medium used in this study was Mushrooms Complete Medium. According to Teoh \& Don (2012), Rodriguez et al. (2018), sources of carbon, nitrogen, and micronutrients such as $\mathrm{KH} 2 \mathrm{PO} 4, \mathrm{~K} 2 \mathrm{HPO} 4$, and $\mathrm{MgSO} 4.7 \mathrm{H} 2 \mathrm{O}$ in the medium influence the production of secondary metabolites. Carbon is the primary source of metabolic processes, nitrogen plays a role as a component of amino acids, while micronutrients are needed as enzyme cofactors for metabolic processes.

The TLC method's detection of secondary metabolites of the alkaloid group using Dragendorff reagent showed positive results indicated by yellow spots. Alkaloid detection results showed that $S$. commune mycelium was positive for alkaloids. The $\mathrm{Rf}$ value of the alkaloid compounds group can be seen in Table 3 .

According to Kumar et al. (2013), a positive interpretation of alkaloids is characterized by yellow to orange spots after the plate is sprayed with Dragendorff's reagent. The $\mathrm{Rf}$ value of alkaloid detection results obtained by TLC can be seen in Table 3. The results obtained are in line with the research of Teoh et al. (2017) that the $S$. commune mushroom extract was positive for alkaloids. Filip et al. (2019) reported that $S$. commune produces an alkaloid compound, namely schizocommunin, which can inhibit cervical cancer cells, it was characterized as a cytotoxic pigment with potential anticancer activity against murine lymphoma.

TLC's deterioration of the secondary metabolites of the terpenoid group was carried out using a vanillin-sulfuric acid reagent. It showed positive results indicated by the presence of blackish-purple spots. The Rf value of the Terpenoid group compounds can be seen in Table 4 .

Table 2. Detection of alkaloid, terpenoid and flavonoid compounds of Schizophyllum commune

\begin{tabular}{lcccccc}
\hline & $\begin{array}{c}\text { Dragendorff } \\
\text { reagent }\end{array}$ & $\begin{array}{c}\text { Vanillin- } \\
\text { sulfuric acid }\end{array}$ & \multicolumn{2}{c}{ AlCl 3 reagent $^{\text {Treatment }}$} \\
\cline { 2 - 6 } & $\begin{array}{c}\text { Alkaloid } \\
\text { group yellow } \\
\text { color }\end{array}$ & $\begin{array}{c}\text { Terpenoid } \\
\text { group violet- } \\
\text { blackish color }\end{array}$ & $\begin{array}{c}\text { Flavonoid } \\
\text { group blue- } \\
\text { green color }\end{array}$ \\
\cline { 2 - 6 } & A & B & A & B & A & B \\
\hline pH 4 & + & + & + & + & + & + \\
pH 5 & + & + & + & + & + & + \\
pH 6 & + & + & + & + & + & + \\
pH 7 & + & + & + & + & + & + \\
\hline
\end{tabular}

Note: +: Detected, -: not detected (-), A. Chloroform solvent, B.

Ethyl acetate solvent

Table 3. Rf value of alkaloid group compounds

\begin{tabular}{lcc}
\hline \multirow{2}{*}{ Treatment } & Alkaloid Rf value & \\
\cline { 2 - 3 } & Chloroform & Ethyl acetate \\
\hline pH 4 & 0.75 & 0.81 \\
pH 5 & 0.56 & 0.81 \\
pH 6 & 0.81 & 0.88 \\
pH 7 & 0.75 & 0.88 \\
\hline
\end{tabular}

Table 4. Rf value of terpenoid group compounds

\begin{tabular}{lll}
\hline \multirow{2}{*}{ Treatment } & \multicolumn{2}{c}{ Terpenoid Rf value } \\
\cline { 2 - 3 } & Chloroform & Ethyl acetate \\
\hline pH 4 & $0.53 ; 0.68 ; 0.94$ & 0.94 \\
pH 5 & $0.063 ; 0.44 ; 0.56 ; 0.69 ; 0.94$ & $0.75 ; 0.94$ \\
pH 6 & $0.063 ; 0.44 ; 0.56 ; 0.69 ; 0.94$ & $0.75 ; 0.94$ \\
pH 7 & $0.063 ; 0.13$ & 0.94. \\
\hline
\end{tabular}


Table 5. Rf value of flavonoid compounds

\begin{tabular}{lcc}
\hline \multirow{2}{*}{ Treatment } & \multicolumn{2}{c}{ Flavonoid Rf value } \\
\cline { 2 - 3 } & Chloroform & Ethyl acetate \\
\hline pH 4 & 0.69 & 0.93 \\
pH 5 & 0.62 & 0.93 \\
pH 6 & 0.62 & 0.93 \\
pH 7 & 0.69 & 0.93 \\
\hline
\end{tabular}
chloroform and ethyl acetate extracts of $S$. commune were positive for containing terpenoids. A positive result is indicated by a change in the color of the spots to blackish purple after spraying the plates with vanillin-sulfuric acid. The $\mathrm{Rf}$ value obtained from the detection of terpenoid compounds can be seen in Table 4. Ivanova (2014) stated that terpenoid is any of a class of hydrocarbons that consist of terpenes attached to an oxygen-containing group. In turn, the terpene is any form of hydrocarbons class consisting of two or more isoprene units joined together. Numerous investigations are devoted to the cytotoxic activity of basidiomycete Ganoderma lucidum triterpenoids (containing six isoprene units). More than 150 triterpenoids were isolated from the fruiting bodies of the genus Ganoderma. Arifni et al. (2017) stated that terpenoids (1,7,7-trimethyl-Bicyclo [2.2.1] heptane-2-one), alkanes (1,3-dimethyl-1-cyclohexene), terpenes ( $\alpha, \alpha, 4$ - trimethyl(S) -3-cyclohexene-1-methanol) has potential for colonic anticancer (WiDr Cancer Cells).

The detection of secondary metabolites of the flavonoid group, which was also carried out by TLC using $\mathrm{AlCl}_{3}$ reagent, showed positive results indicated by greenish-blue spots when viewed in $366 \mathrm{~nm}$ UV light. The Rf value of the flavonoid class compounds can be seen in Table 5 .

The flavonoid detection results showed that the chloroform and ethyl acetate extracts of $S$. commune were positive for flavonoids. A positive effect is indicated by a greenish-blue spot after the plate is sprayed with $\mathrm{AlCl} 3$ reagent observed in $366 \mathrm{~nm}$ UV light. Yao et al. (2016) stated that five phenolic acids identified from $S$. commune extracts in the present study included vanillic acid, $m$ hydroxybenzoic acid, $o$-hydroxybenzene acetic acid, 3hydroxy-5-methyl benzoic acid, and p-hydroxybenzoic acid. Patel and Goyal (2012) reported that bioactive metabolites class of terpenoids, steroids, phenolics, flavonoids, and alkaloids are potential anticancer compounds.

The bioactive compounds produced by $S$. commune are terpenoids, flavonoids, and alkaloids. $S$. commune potentially inhibits the four cancer cell lines used with $\mathrm{IC}_{50}$ values ranging from 5.44 to $420.48 \mu \mathrm{g} / \mathrm{mL}$ and the four cancer cell lines were died by apoptosis. Best results are obtained from the chloroform extract of $S$. commune in T47D cells with IC50 $=5.44 \mu \mathrm{g} / \mathrm{mL}$. Cell cycle testing is necessary to determine the inhibition of cell lines replication.

\section{ACKNOWLEDGEMENTS}

The author's gratitude goes to the Unsoed Research and Community Service Institute (LPPM), which has provided research funds through the Riset Institusi Unsoed (RIU) scheme in 2019; the author also thanks to the LPPM staff who have provided facilities, information, and cooperation, as well as the Dean of the Faculty of Biology Unsoed who have permitted this study.

\section{REFERENCES}

Abo-Elmag HI. 2014. Evaluation and Optimization of Antioxidant Potentiality of Chaetomium madrasense AUMC 9376. J Genet Eng Biotechnol 12: 21-26.

Ackermann T, Tardito S. 2019. Cell culture medium formulation and its implications in cancer metabolism. Trends Cancer 5 (6): 329-332.

Arifni FR, Hasan AEZ, Hasim, Julistiono H, Husnawaty, Bermawie N, and Riyanti EI. 2017. Anticancer activities of endophytic fungi isolated from soursop leaves (Annona muricata L.) against WiDr cancer cells. Ann Res Rev Biol 18 (5): 1-11.

Ashraf MA. 2020. Phytochemicals as potential anticancer drugs: time to ponder nature's bounty. BioMed Res Intl 2020: 1-7, DOI: $10.1155 / 2020 / 8602879$.

Biswas G, Sarkar S, Acharya K. 2010. Free radical scavenging and antiinflammatory activities of the extracts of Astraeus hygrometricus (Pers.) Morg. Latin Am J Pharm 29 (4): 549-553.

Brady HJM. 2007. Apoptosis Methods and Protocols. Humana Press Inc., Totowa, NJ.

Cai L. 2014. Current Protocols Essential Laboratory Techniques - Thin Layer Chromatography. University of South Carolina, Columbia, NC. DOI: 10.1002/9780470089941.et0603s08.

Ekowati N, Mumpuni A, Muljowati JS. 2017. Effectiveness of Pleurotus ostreatus extracts through cytotoxic test and apoptosis mechanism of cervical cancer cells. Biosaintifika 9 (1) 48-155.

Faridur RM, Rezaul KM, Farhadul IM, Rowshanul HM, Toffazal HM. 2010. Phytochemical and cytotoxic investigation and oyster mushroom (Pleurotus ostreatus). Intl Res J Pharm 1 (1): 342-345.

Filip R, Shaw T, Nishida A, and Pezacki JP. 2019. Fungal natural alkaloid schizocommunin activates the aryl hydrocarbon receptor pathway. Med Chem Commun 10: 985-990.

Ghosh SK, Sanyal T, Bera T. 2020. Anticancer activity of solvent extracts of Hexogonia glabra against cervical cancer cell lines. Asian Pac J Cancer Prev 21 (7): 1977-1986.

Hikam AR, Ekowati N, Hernayanti. 2019. The cytotoxic and apoptosis effects of chloroform extracts of Auricularia auricula on cervical cancer cells. Biosaintifika 11 (1): 32-38.

Ivanova TS, Krupodorova TA, Barshteyn VY, Artamonova AB, Shlyakhovenko VA. 2014. Anticancer substances of mushroom origin. Exp Oncol 36 (2): 58-66.

Khatun S, Islam A, Cakilcioglu U, and Chatterjee NC. 2012. Research on mushroom as a potential source of nutraceuticals: a review on Indian perspective. Amer J Exp Agric 2 (1): 47-73.

Kumar S, Jyotirmayee K, Sarangi M. 2013. Thin Layer Chromatography: A tool of biotechnology for isolation of bioactive compounds from medicinal plants. Intl J Pharm Sci Rev Res 18 (1): 126-132.

Lee HH, Lee S, Lee K, Shin YS, Kang H, and Cho H. 2015. Anticancer effect of Cordyceps militaris in human colorectal carcinoma RKO cells via cell cycle arrest and mitochondrial apoptosis. Daru J Pharmaceut Sci 23 (35): 1-8.

Liu RH, Chen S, Lu LM, Tsai W, Tsai C, Yang C, and Tzeng YM. 2014. Selective apoptotic cell death effects of oral cancer cells treated with destruxin B. 1. BMC Compl Altern Med 14 (207): 1-10.

Meerloo JV. 2011. Cell sensitivity assays: the MTT assay. Cancer cell culture: methods and protocols. Methods in Molecular Biology. Amsterdam University Medical Center Amsterdam, Netherlands.

Meiyanto E, Susidarti RA, Handayani S, Rahmi F. 2008. Ethanolic extract of areca catechu (Areca catechu L.) seeds is able to inhibit proliferation and stimulate apoptosis of MCF-7 cells. Indon Pharma Mag 19 (1): 12-19. 
Menakongka A, Ruaengsritanyakij S, Sripayak S, Suthiphongchai T 2019. Antiproliferation and anti-migration of Schizophyllum commune extract on Human Cholangiocarcinoma Cell Line. Vajira Med J J Urban Med 63 (5): 325-335.

Moharib SA, Maksoud NAL, Ragab HM, and Shehata MM. 2014 Anticancer activities of mushroom polysaccharides on chemically induced colorectal cancer in rats. J Appl Pharmaceut Sci 4 (7): 54-63.

Morris HJ, Beltrán Y, Llauradó G, Batista PL. Perraud-Gaime I, García N, Moukha S, Bermúdez RC, Cos P, Hernández E, Diez JC. 2017. Mycelia from Pleurotus sp. (oyster mushroom): a new wave of antimicrobials, anticancer and antioxidant bio-ingredients. Intl J Phytocos Nat Ingred 4 (3): 1-9

Patel S, Goyal A. 2012. Recent developments in mushrooms as anticancer therapeutics: a review. Biotech 2: 1-15.

Rodriguez AR, Carmona NM, Villafan BR, Koirala N, Rocha D, Sanchez S. 2018. Interplay between carbon, nitrogen, and phosphate utilization in the control of secondary metabolite production in Streptomyces. Antonie van Leeuwenhoek 111 (5): 761-781.
Song FQ, Liu Y, Kong XS, Chang W, Song G. 2013. Progress on understanding the anticancer mechanisms of medicinal mushroom: Inonotus obliquus. Asian Pacific J Cancer Prev, 14 (3): 1571-1578.

Teoh YP, Don MM, Ujang S. 2017. Production of biomass by Schizophyllum commune and its antifungal activity towards rubberwood-degrading fungi. Sains Malaysiana 46 (1): 123-128.

Teoh YP, Don MM. 2012. Nutrient improvement using statistical optimization for growth of Schizophyllum commune, and its antifungal activity against wood degrading fungi of rubberwood. Biotechnol Prog 28 (1): 232-241.

Torre LA, Bray F, Siegel RL, Ferlay J, Lortet-Tieulent J, Jemal A. 2015. Global cancer statistics, 2012. Ca Cancer J Clin 65: 87-108.

Yao HM, Wang G, Liu YP, Rong MQ, Shen CB, Yan XW, Luo DX, Lai R. 2016. Phenolic acids isolated from the fungus Schizophyllum commune exert analgesic activity by inhibiting voltage-gated sodium channels. Chinese J Nat Med 14 (9): 661-670. 